\title{
Oran Young and international institutions
}

\section{Ronald B. Mitchell}

\section{International Environmental Agreements: Politics, Law and Economics}

ISSN 1567-9764

Volume 13

Number 1

Int Environ Agreements (2013) 13:1-14 DOI 10.1007/s10784-012-9200-3

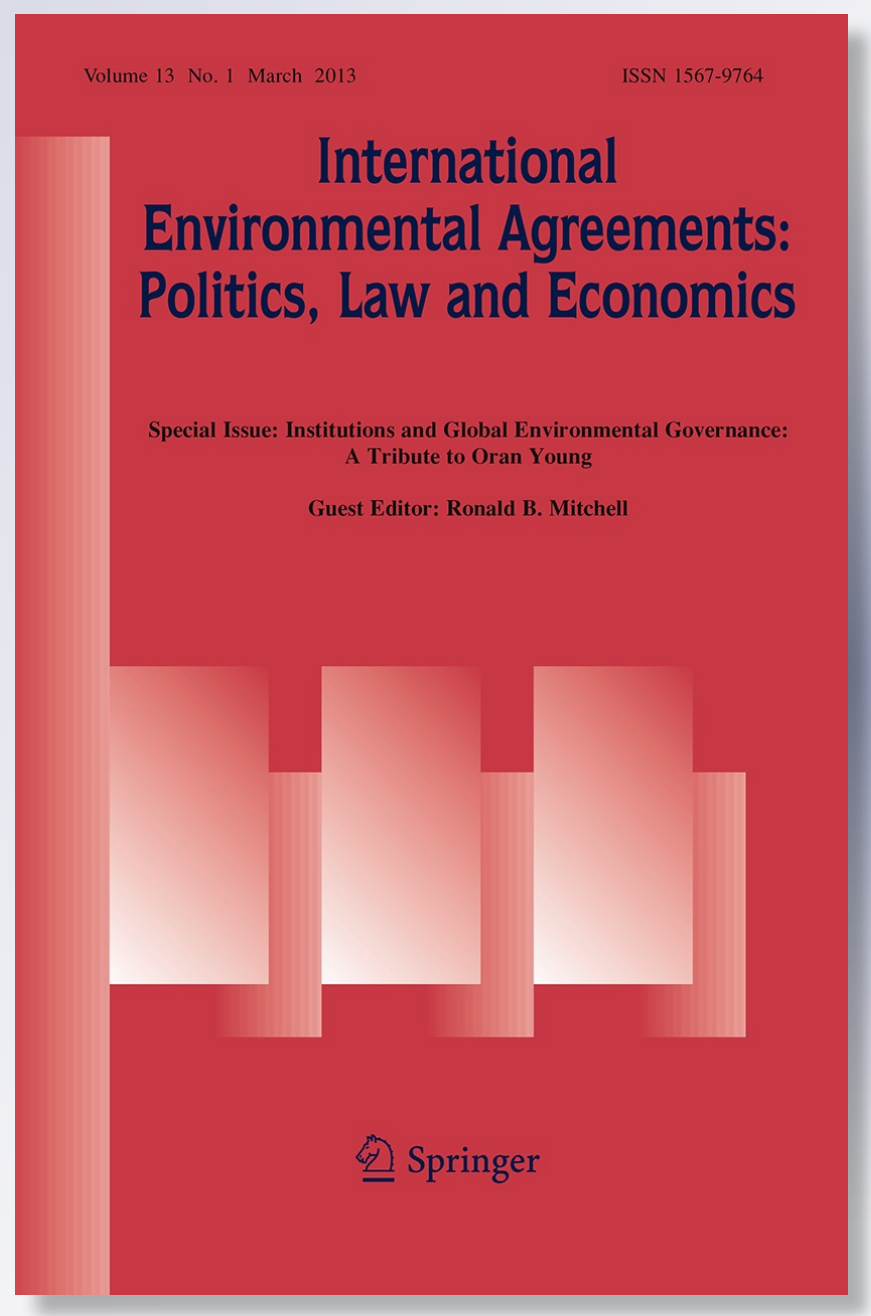

Springer 
Your article is protected by copyright and all rights are held exclusively by Springer Science +Business Media Dordrecht. This e-offprint is for personal use only and shall not be selfarchived in electronic repositories. If you wish to self-archive your work, please use the accepted author's version for posting to your own website or your institution's repository. You may further deposit the accepted author's version on a funder's repository at a funder's request, provided it is not made publicly available until 12 months after publication. 


\title{
Oran Young and international institutions
}

\author{
Ronald B. Mitchell
}

Accepted: 15 November 2012/Published online: 28 November 2012

(C) Springer Science+Business Media Dordrecht 2012

\begin{abstract}
Current understandings of global environmental governance owe much to the numerous theoretical, empirical, and methodological contributions of Oran Young. Over the course of 50 years, Young has created many of the theories and typologies we use to explain why international environmental institutions form and what types of effects they have and the conditions under which they have them. His contributions have been central to the development of the concepts of institutional dynamics, interplay, and scale. He has made major contributions to environmental policy globally and in the Arctic, both through his own work and by fostering the work of other scholars. This article summarizes the contributions Young has made to the field and introduces the articles in this special issue that honor those contributions.
\end{abstract}

Keywords Global environmental governance - International regimes · Effectiveness

$\begin{array}{ll}\text { Abbreviations } \\ \text { ETS } & \text { Emissions Testing Service } \\ \text { EU } & \text { European Union } \\ \text { IDGEC } & \text { Institutional Dimensions of Global Environmental Change } \\ \text { IHDP } & \text { International Human Dimensions Programme } \\ \text { IRD } & \text { International Regimes Database } \\ \text { NGO } & \text { Non-governmental Organization } \\ \text { NSF } & \text { National Science Foundation }\end{array}$

For 50 years, Oran Young has fostered our understanding of international institutions. Over that time, Young has coupled remarkable perseverance in seeking to explain international cooperation and institutions with an impressive ability to innovate and evolve in

R. B. Mitchell ( ()

Department of Political Science and Program in Environmental Studies,

University of Oregon, Eugene, OR 97403-1284, USA

e-mail: rmitchel@uoregon.edu 
his thinking, identify new research questions and perspectives, develop new conceptual tools and models, challenge scholars to deploy more rigorous methods, and generate findings that contribute both to policy-makers and to scholars of global environmental governance and international relations. This special issue of INEA seeks to honor the many contributions, summarized in this article, that Young has made to the study of global environmental governance in particular.

It is particularly appropriate to honor Oran Young in this journal. Young has supported INEA since its inception in 2001, writing a seminal piece that anchored the journal's first issue and being an original member of its Advisory Board (Young 2001). As an associate editor since 2004, he has helped shape INEA policies and improve the quality of articles INEA publishes. The INEA Editorial Team and the contributors to this issue seek to honor Young's numerous contributions to the field through this special issue.

\section{A brief intellectual history}

Oran Young's publications impress with their range, quantity, quality, and impact. His work spans the international polity writ large and the US Alaska Native Claims Settlement Act, negotiated and imposed regimes, the Cuban Missile crisis and Chinese nuclear policy, and indigenous peoples and deep sea-bed mining. He has published at least 16 soleauthored books, 4 co-authored books, 11 edited volumes, 60 articles, and more than 20 book chapters. The influence of his articles-including in Science (3), International Organization (4), World Politics (6), and Global Environmental Politics (5) - is attested to by over 1,000 citations of 80 publications (seven with 50 or more) and two circa-1990 articles that still receive more than 10 citations per year. And he exceeded his early productivity of four books and four articles between 1966 and 1968 by publishing four books and 10 articles from 2008 to 2010.

In his early work, Young developed high-level, theoretical, and systemic understandings of international relations and international cooperation, focusing on the role of intermediaries, mediation, bargaining, and interdependence in the realm of security and international crises (Young 1967, 1968a, b, c, d, 1969, 1972a, 1975b, 1978a; Frohlich et al. 1971). During the 1970s, he shifted his theoretical focus to international regimes and institutions and his empirical focus to environmental affairs and Arctic issues, concerns more familiar to INEA's readers. Young made central contributions to the international regimes research program, refining the concept while urging investigations not only of institutional formation, but also of institutional dynamics, effectiveness, and interplay (Young 1979, 1980, 1982a, 1989a, 1989c). Young's reputation as the "godfather" of global environmental governance began with a 1977 book on resource management, following that with various extended treatments of global environmental issues (Young 1977, 1981, 1982b, 1989b). At the same time, he brought attention to emerging security, economic, and environmental issues in the Arctic (Young 1985/86; Osherenko and Young 1989).

By the 1990s, global environmental issues and the Arctic had become Young's exclusive empirical focus (Young 1992a, 1993, 1994a, b, 1996, 1997, 1998; Young and Osherenko 1993a; b; Young et al. 1996). Theoretically, Young extended ideas from his 1979 book on compliance to build a new research program on institutional effectiveness (Young 1979, 1989d, 1992b, 1994a). The work he and his colleagues did on those issues gave a new generation of scholars both the motivation and the methodological tools to examine rigorously the influence of global environmental institutions (Young 1999a; 
Brown Weiss and Jacobson 1998; Chayes and Chayes 1995; Haas et al. 1993; Keohane and Levy 1996; Victor et al. 1998).

Most recently, Young has published several high-level, broad-ranging treatments of global environmental governance, melding his vast knowledge of empirical cases with his skill at identifying important emergent research themes. He has challenged scholars to investigate the fit between environmental problems and institutional solutions, to diagnose institutional problems and address them, to assess the positive and negative effects of interplay among institutions and across scales of governance, to recognize how institutions change over time, and to balance sustainability, efficiency, and equity (Young 2002, 2008b, 2010, 2012).

\section{Substantive themes}

In reviewing his contributions to research into international environmental institutions and global environmental governance, three substantive themes stand out: institutional formation, institutional effects and effectiveness, and institutional dynamics, interplay, and scale.

\subsection{Institutional formation}

Young has been central to the development of regime theory since its inception. Early on, Young defined regimes as "agreements among some specified groups of actors" that spelled out rules of power and authority, rights and liabilities, and behavioral obligations, later noting the important role that "convergent expectations" play in social institutions (Young 1977, 44; 1982b, 16). Krasner's now-standard definition contains many of the same elements, particularly the view that regimes create behavioral expectations (Krasner 1982). Young helped refine the conception of regimes, fostering the transition from studying international organizations to studying international cooperation more generally (Young 1980, 1982a, 1986). Indeed, a 1980 article foreshadows the entire international regimes research program, providing a framework for conceptualizing international regimes, analyzing their effects, and assessing how they change over time (Young 1980).

Young has made numerous contributions to our understanding of why and when international institutions form. He disabused us of the notion that international institutions are always negotiated, noting that they can also form spontaneously or be imposed by dominant states (Young 1989b, 84-89). He highlighted how international institutions vary in terms of whether they are regulatory in nature or seek to foster procedural decisionmaking, programmatic pooling of resources, or generative promotion of norms (Young 1999b, 26-33). His work, along with others, has shown that variation in problem structure influences the difficulty states have in forming international institutions and the features they include in them (Young 1999b, 64-73; Rittberger and Zürn 1991; Miles et al. 2002). His hypotheses regarding regime formation (involving integrative bargaining, equity, focal points, compliance mechanisms, exogenous shocks, and entrepreneurial leaders) remain as germane today as they did two decades ago (Young 1989c; see also, Young and Osherenko 1993a; and Young 1998). And he raised the visibility of efforts by NGOs, corporations, and governments acting unilaterally to address international problems (Osherenko and Young 1989).

Young also has demonstrated that institutional outcomes often reflect process as much as structural forces. Leadership matters for institutional formation, whether it is structural, 
entrepreneurial, or intellectual in form (Young 1991). We capture the outcomes of international negotiations better when we see them as resulting from institutional bargaining rather than from interactions among rational utility-maximizing states or exclusively from hegemonic pressures (Young 1989c, 350-352; 1975a). His work has provided strong theoretical and empirical support for the notion that state interests and positions are exactly what is "in play" in negotiations rather than being "givens" that states bring to-and that remain fixed during-negotiations. Overall, Young has forced scholars interested in institutional formation to see institutions as resulting from relatively static and exogenous forces and also from the dynamic process that is the essence of international negotiations.

\subsection{Institutional effects and effectiveness}

Young has recognized that research on institutional formation is interesting only to the extent that we have clear evidence that international regimes are not, as realists claim, “epiphenomenal" (Young 1992b, 6; Strange 1983). Young's work has been central to building the currently vibrant research program on the effectiveness of international institutions. Early on, Young urged others to recognize that identifying institutional influences-because they can take "subtle and intangible forms"-requires careful analytic attention (Young 1968d, 902).

Young has highlighted the broad potential domain of institutional consequences, distinguishing between institutional effectiveness and institutional effects. Institutional effectiveness refers to an institution's ability to promote its intended goal while institutional effects cast the net more broadly, including those external or indirect impacts an institution may have on a wide range of behaviors and outcomes that the institution does not, nominally, target (Young and Levy 1999, 3-16). Although most research focuses on institutional effectiveness, Young's distinction draws our attention to the idea that, for any given international institution, "the set of possible criteria of evaluation is infinite" (Young 1978 b 192). For example, he assessed the "international polity" as a whole with respect to its effects on "peace or order, distributive justice, environmental quality, and stability" (Young 1978b, 195). Although it is important to assess how arms control agreements have influenced world peace and how trade agreements have influenced international trade, we may, with equal validity, ask how arms control agreements have influenced environmental quality and how trade agreements have influenced the distribution of wealth across and within states.

Young's work also demonstrates the value of clearly operationalizing "effectiveness." He consistently delineates "clear and meaningful criteria" for evaluating institutions (Young 1978b, 191-192; 1999a). This requires choosing an appropriate performance indicator (and proxy for that indicator) and selecting a standard against which performance should be evaluated. An obvious, if not the only, choice for performance indicators (and corresponding proxies) is to use those identified in the treaty, convention, or constitutional documents underlying an international institution. Thus, it seems obvious to ask whether the Convention on Long-Range Transboundary Air Pollution reduced acid rain, whether the International Convention for the Regulation of Whaling reduced whale harvests, and whether the ozone and climate change regimes reduced relevant pollutants. But operationalizing such analyses requires additional choices. As Underdal notes, a researcher must decide whether to evaluate regulatory outputs, behavioral outcomes, or environmental impacts (Underdal 2002, 5-6). Equally, a researcher must choose among approaches that foreground environmental "problem-solving" improvement, legal compliance, economic 
efficiency or cost-effectiveness, promotion of normative goals, or positive behavioral change (Young and Levy 1999, 4-7).

The standard of effectiveness also matters. In an important debate in international environmental politics, Young engaged with Hovi, Sprinz, and Underdal in discussing the merits of different methods for measuring institutional effectiveness (Hovi et al. 2003a, b; Young 2003). That debate demonstrated the value of spirited intellectual exchange while shedding important light on the need to consider-and the challenges to consideringwhether an institution induces "actors to behave differently than they would if the institution did not exist" and whether it achieves as much as it could have, that is, the noregime counterfactual and the "collective optimum" (Young 1992b, 161; Hovi et al. 2003a). Underdal's article in the present volume extends this debate.

Young conceptualizes institutional influence in terms of causal connections and behavioral mechanisms, not merely static independent variables (Young 1999a). A convincing argument that international institutions influence behavior requires a convincing argument regarding the "pathways through which" they do so (Young and Levy 1999, 20). His typology of international institutions serving as utility modifiers, enhancers of cooperation, bestowers of authority, facilitators of learning, role definers, and agents of domestic realignments encompasses the range of theoretical perspectives on the how of institutional influence (Young and Levy 1999, 22-28). Both quantitative and qualitative investigations led by Young have confirmed that accurately understanding institutional influence requires the "open" theoretical perspective for which Young argues. Only models that recognize that institutions can influence state behavior via pathways involving power, interests, norms, knowledge, habit, and the like allow us to assess accurately which pathways explain a given institution's influence (Young and Zürn 2006, 235-236). Finally, Young has provided methodological insights and challenges that have increased the rigor of assessments of institutional effectiveness, fostering projects explicitly focused on methods as well as on in-depth case studies and a large-N database (the International Regimes Database-IRD) (Underdal and Young 2004; Young 1999a; Breitmeier et al. 2006; Breitmeier et al. 2011).

\subsection{Institutional dynamics, interplay, and scale}

Young was an early proponent of attending to institutional dynamics, interplay, and scale as well as institutional formation and institutional consequences. In the 1980s, Young challenged scholars to investigate institutional dynamics, that is, the "developmental patterns or life cycles of regimes" (Young 1982a, 278; 1980, 356). He has divided institutional formation into stages of agenda formation, negotiation, and operationalization stages (Young 1998). More recently, he proposed a typology of five developmental paths for international institutions: progressive development, punctuated equilibrium, arrested development, diversion, and collapse as well as a model of endogenous and exogenous factors that determine which path an institution takes (Young 2010). Some of Young's students and others have taken up the challenge of understanding institutional dynamics (Gehring 1994; Webster 2009). Yet, there remain opportunities for more research into the causes of institutional trajectories and into how an institution's trajectory influences its robustness, resilience, and effectiveness over time.

Young also has drawn our attention to "institutional interplay," to how "issue-specific regimes exhibit complex linkages to other institutional arrangements [that] ... have significant consequences for the outcomes flowing from the ... the affected regimes" (Young 1996, 1). He had recognized early on that institutions can be embedded, nested, clustered, 
or overlapping with other institutions and that treating them as "self-contained or standalone arrangements that can be analyzed in isolation from one another" ran significant analytic risks (Young 1996, 1-2). "Horizontal" interplay among institutions at a given level of governance can reflect conscious or unconscious, proactive or reactive, and successful or unsuccessful efforts by policy-makers to develop potential synergies with other institutions while avoiding duplication, redundancy, and conflict (Young 1996, 2; 2002, 2006). Environmental governance emerges as institutions strive-in coincident or conflicting ways - to frame the issues, choose the arena for institutional development, and bargain over content (Young 2002, 113-132). Whether calling such phenomena institutional linkages, interactions, interplay, overlap, or complexes, Young's work has supported a "third wave" of research that recognizes that an institution's influence is rarely independent of the many other institutions with which it co-exists (Stokke 2001; Raustiala and Victor 2004; Gulbrandsen 2004; Oberthür and Gehring 2006; Young 2008b; Gehring and Oberthür 2008; Jinnah 2010; Oberthür and Stokke 2011; Keohane and Victor 2011).

Institutional interplay is not only horizontal but also "vertical," crossing scales of governance. Governance for any given problem often reflects a layered quilt of explicit and implicit rules and norms that emerge from international, national, subnational, and local levels. Whether such governance prompts improvement, decline, or stasis for any environmental problem, therefore, depends on the extent to which the distribution of competencies, compatibilities, and capacities across these levels "fits" or meshes with attributes of the problem structure, social context, and actors involved (Young 2002, 98ff and 160ff). Issues of scale are increasingly important to global environmental governance because the causes, impacts, and social responses to environmental problems are multiple and occur at and across different scales. An increasing number of scholars are investigating scale and "vertical interplay," generating an increasing consensus (in theory, if not always in practice) that a cross-scale perspective enhances our understanding of the drivers of environmental problems, the influence of science on policy, the diffusion of policy, and institutional influence (Cash and Moser 2000; Cash 2001; Meadowcroft 2002; Young 2002, 2006; Adger et al. 2005; Bulkeley 2005; Mitchell et al. 2006; Cash et al. 2006; Gupta 2008).

\subsection{A certain turn of mind}

Young's work in these three realms has generated a wealth of theoretical hypotheses and carefully analyzed empirical cases. Yet, reading Young's extensive publications also reveals other characteristics of Young's "turn of mind." A first, almost defining, feature of Young's scholarship has been his consistent willingness to accept the complexity of the social world that is international relations. Young has always balked when international relations theorists prove overly willing to sacrifice accuracy on the altar of parsimony (see, for example, Young 1968a; 1969, 750). While Young's conceptual distinctions provide analytic clarity, he recognizes that most concepts of interest in our field-institutions, bargaining, leadership, or effectiveness - are richly complex, non-dichotomous phenomena that demand nuanced analysis, especially if we want them to contribute to real-world policy-making (Young 1991, 281; 1999a, 263ff).

Second, Young consistently balances empirical accuracy with theoretical clarity. Young starts with carefully crafted typologies and hypotheses regarding the causal relationships under investigation and then selects cases that will allow him to evaluate those predictions, showing other scholars how to conduct rigorous empirical analysis while also providing the theoretical framework for doing so. And while much of this work has been qualitative in 
nature, his work with Breitmeier, Zürn, and others on the IRD has "shown the way" for assessing whether qualitative findings hold up across a large number of cases (Breitmeier et al. 2006).

Third, Young has contributed greatly to the methodological sophistication of our field. His own work consistently clarifies the methodological obstacles that his research faces, the strategies he has adopted to overcome them, and the remaining shortcomings of the findings. Beyond those examples from his work, he has more explicitly engaged in methodological debates, recommended methodological strategies, run projects that have trained young scholars, and built large-scale databases like the IRD (Young 1992b, 2003; Hovi et al. 2003a; Breitmeier et al. 2011; Underdal and Young 2004).

Finally, Young has consistently sounded the call that academic scholarship generate "usable knowledge" relevant to policy-makers (Lindblom and Cohen 1979). Early on he bemoaned the fact that "policy-makers should not expect to receive much help from theorists of international relations, at least not in the short run" (Young 1972b, 179). But his work has consistently strived to redress this problem, almost always concluding articles and books with "recommendations for policy-makers" (see, for example, Young 1989a, 1998, 1999a, 2002, 165).

\section{Building international institutions}

Young has dedicated much of his career to building international institutions as well as studying them. His own initiative and requests from those who value his expertise have allowed him to make major contributions to policy and to setting scientific agendas. He "has not only researched governance but has ensured successful governance of research, governance based on collaboration and geared toward education and application" (Maria Gordon personal communication). He helped establish the US National Academy of Sciences' Committee on the Human Dimensions of Global Change in the 1990s. He has played central roles in the International Human Dimensions Programme on Global Environmental Change (IHDP), developing it in the 1990s, chairing its Scientific Committee from 2006 through 2010, leading efforts to write the IHDP Strategic Plan for 2007-2015, and launching IHDP core projects like the Institutional Dimensions of Global Environmental Change (IDGEC) (Young 2002; Young et al. 2008). During his chairmanship, the IHDP Scientific Committee launched the Earth System Governance project (thereby passing the "torch" to the next generation of institution scholars) as well as projects less focused on institutions such as the Integrated Risk Governance Project and the Knowledge, Learning, and Societal Change project. He also co-chaired the Scientific Steering Committee of the Global Carbon Project. Through these and similar efforts, Young has engaged the most promising social scientists across a wide range of disciplines, brought their work to bear on human dimensions topics, placed international social science research on a more-equal footing with the natural sciences, and fostered greater involvement of scholars from the developing world.

Young has also been central to governance in the Arctic. Young recognized the dissolution of the Soviet Union as an opportunity to improve the design of Arctic institutions. Young inspired and chaired a meeting on the Arctic among social scientists from the Russian and American Academies of Science that strengthened the US National Science Foundation's (NSF) support for Arctic programs and sparked numerous research partnerships. Separately, Young and Franklyn Griffiths developed the Working Group on Arctic International Relations (WGAIR) as a forum to promote the idea of the Arctic as a 
distinct international region in the post-cold war, with a policy agenda all its own. Young helped form-and chaired the Governing Board of - the University of the Arctic, a virtual circumpolar university and consortium of universities among the 8 polar states and several other states. He led the Arctic Human Development Report process and provided the intellectual inspiration for the Arctic Social Indicators Project. His contributions have profoundly influenced the quality of life of Arctic communities and helped legitimize the study of the unique interactions between humans and the environment in the Arctic.

\section{Being an international institution}

Young has also been an international institution. As a professor at Princeton University, the University of Texas, the University of Maryland, Dartmouth College, and the University of California at Santa Barbara, he has chaired numerous dissertation committees, including those of Joe Oppenheimer, Norman Frohlich, John Dryzek, and others who have made major contributions in their own right. Many other scholars in global environmental governance consider Young a valued mentor, despite never officially studying under him. Many scholars benefited greatly early in their careers by participating in research projects headed by Young (Young and Osherenko 1993a; Young 1997, 1999a; Underdal and Young 2004). With Breitmeier and Zürn, Young convinced more than 40 scholars to dedicate immense amounts of time to creating the International Regimes Database (Breitmeier et al. 2006). Young's ability to engage scholars in collective projects has had incredible influence on the field because of the faith Young has put in the intelligence of junior scholars and in the value of a collective enterprise to create synergies among junior and more-senior scholars.

Young has committed enormous time, energy, and resources to building an intellectual community of those working on global environmental governance. Most of the millions of grant dollars he has received from the European Union, the United Nations University, the US and foreign science foundations, and from private funders have been dedicated to projects that built an intellectual community. NSF Funding for the IDGEC Project supported a major international conference, brought together numerous scholars, and led to numerous publications culminating in a summary volume (Young et al. 2008). Numerous other grants and his own research funds have been dedicated to getting the right people in the room, whether in the 1991 "Regimes Summit" (Levy et al. 1995) or in the numerous conferences he hosted on international governance, Arctic regions, or specific environmental concerns.

The breadth of Young's interests and the warmth of his personality have made him a central node in the network of global environmental concerns. His research collaborations include scholars in the United States and Europe, as well as in Australia, China, Japan, South Africa, and many developing countries. His unique combination of intellectual and personal traits led a diverse set of 50 scholars - from long-time colleagues such as Elinor Ostrom to his most recent $\mathrm{PhDs}$ - to present 18 papers and celebrate his career at the 2011 Colorado Conference on Earth System Governance (see http://cc2011.earthsystemgovernance.org/CC2011-titleindex.htm).

\section{Articles that follow}

This special issue is dedicated to Oran R. Young and the major contributions to the field that he has made over his career. 
In "Meeting common environmental challenges: The co-evolution of policies and practices," Arild Underdal engages the issues of complexity, regime dynamics, and institutional interplay that have been central to Young's career (Underdal 2013). Underdal develops the concept of "co-evolution" in which institutions improve in their management of environmental problems either through unilateral diffusion or through mutual cooperation. Interdependencies between states-whether they be material or ideational-create incentives for states (particularly laggard states) to adopt policies that they see other similarly situated states using effectively and efficiently to address common problems. Diffusion involves states responding to such incentives with unilateral action. Underdal identifies incongruities, uncertainty, and operational inefficiencies as conditions under which the uncoordinated action of diffusion can create suboptimal outcomes that require international cooperation for their resolution. Building on Young's notion of the need for institutional fit and diagnostics, Underdal argues that power, leadership, and the institutional setting can foster learning that allows institutions to design cooperative arrangements that better fit the characteristics of the problem and, therefore, are more effective (Young 2002, 2008a).

In line with Young's interest in issues of scale and institutional influence, Jon Birger Skjærseth examines the influence of international institutions on firms. In "Governance by EU Emissions Trading (ETS): resistance or innovation in the oil industry?" Skjærseth develops a framework for understanding why corporate responses to international regulation may initially diverge and also why they, subsequently, converge (Skjærseth 2013). Exxon initially opposed the ETS which it saw as a regulatory threat while Shell embraced it as a business opportunity. Over time, however, these companies' responses converged. Skjærseth argues that firms either can focus on the costs of regulation, responding as reluctant adapters, or can focus on the new opportunities regulations create, responding as innovators. He finds that companies are more likely to adopt the latter approach if there is "a high degree of institutional fit between the ETS and pre-existing or evolving relevant national policy instruments." Skjærseth's careful analysis of Shell and Exxon identifies the conditions under which regulation prompts innovation and those that inhibit it from doing so, noting in particular that Shell's embrace of the new regulations owed much to its "dynamic capabilities" (i.e., the freedom of action given to managers). Paralleling much of Young's focus on the complex ways in which institutions influence behavior, Skjærseth helps identify the conditions that prompt two actors to respond quite differently to the same regulatory pressures (Young 1999a).

Øistein Harsem and Alf Håkon Hoel also engage Young's concept of institutional fit by examining the ability of Arctic institutions to respond effectively to the new challenges posed for fisheries by predicted climate change (Harsem and Hoel 2013). Using the national and international efforts to manage Norway's fisheries, they find that effective management of a dynamic natural system requires management institutions to integrate three critical management functions. The management institution must have access to, and respond to, new science regarding the state of the natural system or the processes by which the natural system operates. It must be able to adopt appropriate regulations promptly in response to that new science. And there must be an effective enforcement system that ensures that changes in regulations prompt corresponding changes in behavior relatively promptly and efficiently. The dynamic nature of fisheries has always required that fishery management systems be adaptive to be effective. As climate change transforms previously stable environmental systems into dynamic systems, relevant institutions would be well advised to learn from the experience of effective fisheries institutions. 
In "Regime interplay in Arctic shipping governance: Explaining regional niche selection," Olav Schram Stokke helps us understand institutional interaction and interplay by showing how regimes that are part of larger institutional complexes specialize in certain governance tasks (Stokke 2013). Building on Young's work, Stokke finds the various institutions involved with Arctic marine transport have adopted a division of labor in which regional and global institutions fill different governance "niches" based on the fit between their capacities and particular governance tasks. Thus, the regional Arctic Council fosters scientific knowledge to prompt new regulation (while leaving adoption of those regulations to other institutions); it also builds capacities to address oil spills, marine search and rescue, and other tangible problems. Stokke's insights extend the growing research program on institutional interplay and regime complexes by urging assessment of how to best integrate the capacities of global and regional institutions to foster more effective environmental management (Keohane and Victor 2011; Young 2008b).

Finally, we are fortunate to have Oran Young himself distill the major insights of his career in the final article of this special issue of INEA. With his usual clarity and rigor, Young begins by providing clear definitions of concepts that he has been central to developing: governance, institutions, regimes, organizations, and effectiveness. Reflecting his belief that scale matters but that lessons from one level may apply to another, Young delineates ten propositions about environmental governance that apply at all levels of social organization and five others that apply more exclusively to the international level. He reviews important contributions he has made regarding environmental governance generally, including that there can be governance without government, that institutional outcomes depend on bargaining and individuals (not just pre-existing interests), that institutions emerge through different processes and take different forms depending on the problem structure from which they arise, that they influence behavior through an array of mechanisms that are not limited to instrumental influences, that uncertainty plays a role in institutional effectiveness, and that institutional fit matters. Equally important, he notes that international environmental governance is possible despite the constraints of anarchy, that both institutional interplay and institutional dynamics matter considerably for institutional outcomes, and that institutional influence involves a multi-leveled game that must extend below the state. Although he notes four important methodological challenges that may hinder progress, he concludes with a valuable reminder of the importance that he attaches to ensuring that we convert scholarship into "usable knowledge." Perhaps most tellingly, Young points to the ways in which the challenges being created by "the onset of the Anthropocene" are making it ever more urgent that scholars and practitioners accurately diagnose environmental problems and design institutions that "fit" those problems as currently understood and that can adapt as our understandings change, a point built on by Harsem and Hoel in their article in this issue (Young 2013).

\section{Conclusion}

Oran Young's career has provided us with innumerable insights into international cooperation. Without those contributions, the scholarly world of global environmental governance would be far poorer both theoretically and empirically. He has challenged scholars working in the field to engage in analytically critical research that helps us resolve-rather than merely understand-the pressing environmental problems we face. He has consistently embraced theoretical clarity while rejecting theoretical parsimony that ignores realworld complexities, interactions, and ambiguities. He has given numerous scholars the 
intellectual and methodological tools, and practical examples, for conducting research that builds on and extends existing theory while contributing to real-world policy. Throughout his career, Young has conducted and framed his analyses of global environmental politics in ways that have appealed to, engaged, and gained recognition from the broader international relations community of scholars while fostering the efforts of those scholars and practitioners most attentive to the environmental problems our planet faces.

Acknowledgments I wish to thank Michele Betsill, Maria Gordon, Franklyn Griffiths, Joyeeta Gupta, Agni Kalfagianni, Leslie King, Gail Osherenko, Carmen Scherkenbach, Falk Schmidt, Heike Schroeder, and Arild Underdal for contributions to and comments on this article as it developed. Remaining errors remain the responsibility of the author.

\section{References}

Adger, W. N., Arnell, N. W., \& Tompkins, E. (2005). Successful adaptation to climate change across scales. Global Environmental Change, 15(2), 77-86.

Breitmeier, H., Underdal, A., \& Young, O. R. (2011). The effectiveness of international environmental regimes: Comparing and contrasting findings from quantitative research. International Studies Review, 13(4), 579-605.

Breitmeier, H., Young, O. R., \& Zürn, M. (2006). Analyzing international environmental regimes: From case study to database. Cambridge, MA: MIT Press.

Brown Weiss, E., \& Jacobson, H. K. (Eds.). (1998). Engaging countries: Strengthening compliance with international environmental accords. Cambridge, MA: MIT Press.

Bulkeley, H. (2005). Reconfiguring environmental governance: Towards a politics of scales and networks. Political Geography, 24(8), 875-902.

Cash, D. W. (2001). "In order to aid in diffusing useful and practical information... ": cross-scale boundary organizations and agricultural extension. Science, Technology and Human Values, 26(4), 431-453.

Cash, D. W., Adger, W. N., Berkes, F., Garden, P., Lebel, L., \& Olsson, P., et al. (2006). Scale and cross-scale dynamics: Governance and information in a multilevel world. Ecology and Society, 11(2), Article 8.

Cash, D. W., \& Moser, S. C. (2000). Linking global and local scales: Designing dynamic assessment and management processes. Global Environmental Change, 10(2), 109-120.

Chayes, A., \& Chayes, A. H. (1995). The new sovereignty: Compliance with international regulatory agreements. Cambridge, MA: Harvard University Press.

Frohlich, N., Oppenheimer, J. A., \& Young, O. R. (1971). Political leadership and collective goods. Princeton, N.J.: Princeton University Press.

Gehring, T. (1994). Dynamic international regimes: Institutions for international environmental governance. Frankfurt am Main: P. Lang.

Gehring, T., \& Oberthür, S. (2008). Interplay: Exploring institutional interaction. In O. R. Young, L. A. King, \& H. Schroeder (Eds.), Institutions and environmental change: Principal findings, applications, and research frontiers (pp. 187-224). Cambridge, MA: MIT Press.

Gulbrandsen, L. H. (2004). Overlapping public and private governance: Can forest certification fill the gaps in the global forest regime? Global Environmental Politics, 4(2), 75-99.

Gupta, J. (2008). Global change: Analyzing scale and scaling in environmental governance. In O. R. Young, L. A. King, \& H. Schroeder (Eds.), Institutions and environmental change: Principal findings, applications, and research frontiers (pp. 225-258). Cambridge, MA: MIT Press.

Haas, P. M., Keohane, R. O., \& Levy, M. A. (Eds.). (1993). Institutions for the earth: Sources of effective international environmental protection. Cambridge, MA: MIT Press.

Harsem, Ø., \& Hoel, A. H. (2013). Climate change and adaptive capacity in fisheries management: The case of Norway. International Environmental Agreements, 13(1), 49-63.

Hovi, J., Sprinz, D. F., \& Underdal, A. (2003a). The Oslo-Potsdam solution to measuring regime effectiveness: Critique, response, and the road ahead. Global Environmental Politics, 3(3), 74-96.

Hovi, J., Sprinz, D. F., \& Underdal, A. (2003b). Regime effectiveness and the Oslo-Potsdam solution: a rejoinder to Oran Young. Global Environmental Politics, 3(3), 105-107.

Jinnah, S. (2010). Overlap management in the World Trade Organization: Secretariat influence on tradeenvironment politics. Global Environmental Politics, 11(2), 54-79. 
Keohane, R. O., \& Levy, M. A. (Eds.). (1996). Institutions for environmental aid: Pitfalls and promise. Cambridge, MA: MIT Press.

Keohane, R. O., \& Victor, D. G. (2011). The regime complex for climate change. Perspectives on Politics, 9(1), 7-23.

Krasner, S. D. (1982). Structural causes and regime consequences: Regimes as intervening variables. International Organization, 36(1), 185-205.

Levy, M. A., Young, O. R., \& Zürn, M. (1995). The study of international regimes. European Journal of International Relations, 1(3), 267-330.

Lindblom, C. E., \& Cohen, D. K. (1979). Usable knowledge: Social science and social problem solving. New Haven: Yale University Press.

Meadowcroft, J. (2002). Politics and scale: Some implications for environmental governance. Landscape and Urban Planning, 61(1), 169-179.

Miles, E. L., Underdal, A., Andresen, S., Wettestad, J., Skjærseth, J. B., \& Carlin, E. M. (Eds.). (2002). Environmental regime effectiveness: Confronting theory with evidence. Cambridge, MA: MIT Press.

Mitchell, R. B., Clark, W. C., Cash, D. W., \& Dickson, N. (Eds.). (2006). Global environmental assessments: Information and influence. Cambridge, MA: MIT Press.

Oberthür, S., \& Gehring, T. (Eds.). (2006). Institutional interaction in global environmental governance: Synergy and conflict among international and EU policies. Cambridge, MA: MIT Press.

Oberthür, S., \& Stokke, O. S. (2011). Managing institutional complexity : Regime interplay and global environmental change (Institutional dimensions of global environmental change). Cambridge, Mass: MIT Press.

Osherenko, G., \& Young, O. R. (1989). The age of the Arctic: Hot conflicts and cold realities. Cambridge, UK: Cambridge University Press.

Raustiala, K., \& Victor, D. G. (2004). The regime complex for plant genetic resources. International Organization, 58(2), 277-310.

Rittberger, V., \& Zürn, M. (1991). Regime theory: Findings from the study of East-West regimes. Cooperation and Conflict, 26(4), 165-183.

Skjærseth, J. B. (2013). Governance by EU Emissions Trading (ETS): resistance or innovation in the oil industry. International Environmental Agreements, 13(1), 31-48.

Stokke, O. S. (Ed.). (2001). Governing high seas fisheries: The interplay of global and regional regimes. Oxford: Oxford University Press.

Stokke, O. S. (2013). Regime interplay in Arctic shipping governance: Explaining regional niche selection. International Environmental Agreements, 13(1), 65-85.

Strange, S. (1983). Cave! hic dragones: A critique of regime analysis. In S. D. Krasner (Ed.), International regimes (pp. 337-354). Ithaca, NY: Cornell University Press.

Underdal, A. (2002). One question, two answers. In E. L. Miles, A. Underdal, S. Andresen, J. Wettestad, J. B. Skjærseth, \& E. M. Carlin (Eds.), Environmental regime effectiveness: Confronting theory with evidence (pp. 3-45). Cambridge, MA: MIT Press.

Underdal, A. (2013). Meeting common environmental challenges: The co-evolution of policies and practices. International Environmental Agreements, 13(1), 15-30.

Underdal, A., \& Young, O. R. (Eds.). (2004). Regime consequences: Methodological challenges and research strategies. Dordrecht: Kluwer.

Victor, D. G., Raustiala, K., \& Skolnikoff, E. B. (Eds.). (1998). The implementation and effectiveness of international environmental commitments: Theory and practice. Cambridge, MA: MIT Press.

Webster, D. G. (2009). Adaptive governance: The dynamics of Atlantic fisheries management. Cambridge, MA: MIT Press.

Young, O. R. (1967). The intermediaries: Third parties in international crises. Princeton, NJ: Princeton University Press.

Young, O. R. (1968a). Political discontinuities in the international system. World Politics, 20(3), 369-392.

Young, O. R. (1968b). The politics of force: Bargaining during international crises. Princeton, NJ: Princeton University Press.

Young, O. R. (1968c). Systems of political science (Foundations of modern political science series). Englewood Cliffs, N.J.: Prentice-Hall.

Young, O. R. (1968d). The United Nations and the international system. International Organization, 22(4), 902-922.

Young, O. R. (1969). Interdependencies in world politics. International Journal, 24(4), 726-750.

Young, O. R. (1972a). Intermediaries: Additional thoughts on third parties. Journal of Conflict Resolution, $16(1), 5165$.

Young, O. R. (1972b). The perils of Odysseus: On constructing theories of international relations. World Politics, 24(Supplement), 179-203. 
Young, O. R. (1975a). The analysis of bargaining: Problems and prospects. In O. R. Young (Ed.), Bargaining : Formal theories of negotiation (pp. 391-408). Urbana: University of Illinois Press.

Young, O. R. (1975b). Bargaining : Formal theories of negotiation. Urbana: University of Illinois Press.

Young, O. R. (1977). Resource management at the international level: The case of the North Pacific. New York: Pinter and Nichols.

Young, O. R. (1978a). Anarchy and social choice: Reflections on the international polity. World Politics, 30(2), 241-263.

Young, O. R. (1978b). On the performance of the international polity. British Journal of International Studies, 4(3), 191-208.

Young, O. R. (1979). Compliance and public authority : A theory with international applications. Baltimore: Published for Resources for the Future by the Johns Hopkins University Press.

Young, O. R. (1980). International regimes: Problems of concept formation. World Politics, 32(3), 331-356.

Young, O. R. (1981). Natural resources and the state: The political economy of resource management (Studies in international political economy). Berkeley: University of California Press.

Young, O. R. (1982a). Regime dynamics: The rise and fall of international regimes. International Organization, 36(2), 277-297.

Young, O. R. (1982b). Resource regimes : Natural resources and social institutions. Berkeley: University of California Press.

Young, O. R. (1985/86). The age of the Arctic. Foreign Policy, 61, 160-179.

Young, O. R. (1986). International regimes: Toward a new theory of institutions (review of After Hegemony: Cooperation and Discord in the World Political Economy by Robert O. Keohane; International Regimes by Stephen D. Krasner; and The Antinomies of Interdependence by John G. Ruggie). World Politics, 39(1), 104-122.

Young, O. R. (1989a). International cooperation : Building regimes for natural resources and the environment. Ithaca: Cornell University Press.

Young, O. R. (1989b). International cooperation: Building regimes for natural resources and the environment. Ithaca, NY: Cornell University Press.

Young, O. R. (1989c). The politics of international regime formation: Managing natural resources and the environment. International Organization, 43(3), 349-376.

Young, O. R. (1989d). The power of institutions: why international regimes matter. In O. R. Young (Ed.), International cooperation: Building regimes for natural resources and the environment (pp. 58-80). Ithaca, NY: Cornell University Press.

Young, O. R. (1991). Political leadership and regime formation: On the development of institutions in international society. International Organization, 45(3), 281-308.

Young, O. R. (1992a). Arctic politics : Conflict and cooperation in the circumpolar North. Hanover: University Press of New England.

Young, O. R. (1992b). The effectiveness of international institutions: hard cases and critical variables. In J. N. Rosenau \& E.-O. Czempiel (Eds.), Governance without government: Change and order in world politics (pp. 160-194). New York: Cambridge University Press.

Young, O. R. (1993). International organizations and international institutions: Lessons learned from environmental regimes. In S. Kamieniecki (Ed.), Environmental politics in the international arena (pp. 145-164). Albany: State University of New York Press.

Young, O. R. (1994a). International governance: Protecting the environment in a stateless society. Ithaca, NY: Cornell University Press.

Young, O. R. (1994b). The problem of scale in human/environment relationships. Journal of Theoretical Politics, 6(4), 429-447.

Young, O. R. (1996). Institutional linkages in international society: Polar perspectives. Global Governance, 2(1), 1-24.

Young, O. R. (Ed.). (1997). Global governance: Drawing insights from the environmental experience. Cambridge, MA: MIT Press.

Young, O. R. (1998). Creating regimes : Arctic accords and international governance. Ithaca: Cornell University Press.

Young, O. R. (Ed.). (1999a). The effectiveness of international environmental regimes: Causal connections and behavioral mechanisms. Cambridge, MA: MIT Press.

Young, O. R. (1999b). Governance in world affairs. Ithaca, NY: Cornell University Press.

Young, O. R. (2001). The behavioral effects of environmental regimes: Collective-action vs. social-practice models. International Environmental Agreements, 1(1), 9-29.

Young, O. R. (2002). The institutional dimensions of environmental change: Fit, interplay, and scale. Cambridge, MA: MIT Press. 
Young, O. R. (2003). Determining regime effectiveness: A commentary on the Oslo-Potsdam solution. Global Environmental Politics, 3(3), 97-104.

Young, O. R. (2006). Vertical interplay among scale-dependent environmental and resource regimes. Ecology and Society, 11(1), Article 27.

Young, O. R. (2008a). Building regimes for socioecological systems: Institutional diagnostics. In O. R. Young, L. A. King, \& H. Schroeder (Eds.), Institutions and environmental change: Principal findings, applications, and research frontiers (pp. 115-143). Cambridge, MA: MIT Press.

Young, O. R. (2008b). Institutional interplay : Biosafety and trade. Tokyo, Japan: United Nations University.

Young, O. R. (2010). Institutional dynamics : Emergent patterns in international environmental governance. Cambridge, MA: MIT Press.

Young, O. R. (2012). On environmental governance : Sustainability, efficiency, and equity (On politics). Boulder: Paradigm Publishers.

Young, O. R. (2013). Sugaring off: enduring insights from long-term research on environmental governance. International Environmental Agreements, 13(1), 87-105.

Young, O. R., Demko, G. J., \& Ramakrishna, K. (1996). Global environmental change and international governance. Hanover: University Press of New England.

Young, O. R., King, L. A., \& Schroeder, H. (Eds.). (2008). Institutions and environmental change: Principal findings, applications, and research frontiers. Cambridge, MA: MIT Press.

Young, O. R., \& Levy, M. A. (1999). The effectiveness of international environmental regimes. In O. R. Young (Ed.), The effectiveness of international environmental regimes: Causal connections and behavioral mechanisms (pp. 1-32). Cambridge, MA: MIT Press.

Young, O. R., \& Osherenko, G. (Eds.). (1993a). Polar politics: Creating international environmental regimes. Ithaca, NY: Cornell University Press.

Young, O. R., \& Osherenko, G. (1993b). Testing theories of regime formation: Findings from a large collaborative research project. In V. Rittberger (Ed.), Regime theory and international relations (pp. 223-251). New York: Oxford University Press.

Young, O. R., \& Zürn, M. (2006). The international regimes database: Designing and using a sophisticated tool for institutional analysis. Global Environmental Politics, 6(3), 121-143. 